Pathologe 2022 $\cdot 43: 16-30$

https://doi.org/10.1007/s00292-021-01015-7

Accepted: 23 September 2021

Published online: 12 November 2021

(c) Springer Medizin Verlag $\mathrm{GmbH}$, ein Teil von

Springer Nature 2021, korrigierte Publikation 2021

Schwerpunktherausgeber

H.I. Grabsch, Maastricht, Niederlande

R. Langer, Linz, Österreich

M. Vieth, Bayreuth

\section{Histologic features of colonic infections}

\author{
Maria Westerhoff \\ University of Michigan, Ann Arbor, USA
}

\title{
Abstract
}

Background: The histopathologic diagnosis of infectious colitis remains relevant despite recent advances in microbiologic techniques.

Objective: This article aims to describe the histologic features of selected infectious diseases of the colon.

Materials and methods: Existing reports on histopathologic and clinical aspects of colonic infectious agents were reviewed.

Results: While histology alone may not be as sensitive as current microbiologic methods, tissue identification of infectious agents still plays an important role in patient care. Infectious colitis can have a variety of clinical manifestations, ranging from strongyloidiasis, which can cause a smoldering, subclinical infection for decades, to syphilis, which can clinically mimic cancer or inflammatory bowel disease. Therefore, the histopathologic identification of infection as the cause of a patient's colitis has a considerable impact on treatment decisions. Morphologic overlap can occur between infection and other diseases, however. Moreover, some infections can elicit various tissue responses beyond acute colitis. Immunosuppressed patients may not mount an inflammatory response to pathogens such as cytomegalovirus or adenovirus. Sexually transmitted proctocolitis can cause plasma-cell-rich inflammation. Gastrointestinal histoplasmosis is more likely to cause diffuse histiocyte infiltration rather than the expected granuloma formation. In some cases, ancillary tests are useful, but equivocal results can cause diagnostic dilemmas.

Conclusion: Given the range with which colonic infectious disorders can manifest, pathologists should be aware of the typical features of infectious colitis, as well as findings beyond the classic morphologies.

\section{Keywords}

Gastrointestinal pathology · Viral colitis - Parasitic infection - Bacterial colitis · Sexually transmitted proctitis

\section{Introduction}

Infectious colitis can exhibit a range of manifestations and mimic diseases treated by immunosuppression. A variety of diagnostic techniques are available beyond that of histology, such as immunohistochemistry (IHC) and molecular analysis. Nevertheless, it is still important to be able to recognize the tissue appearance and clinical significance of infectious agents, as well as the types of inflammatory responses they may elicit. The fact that diagnoses may be time sensitive and that differential diagnoses may include conditions with treatments that can worsen infection underscores the importance of proper histologic recognition. 

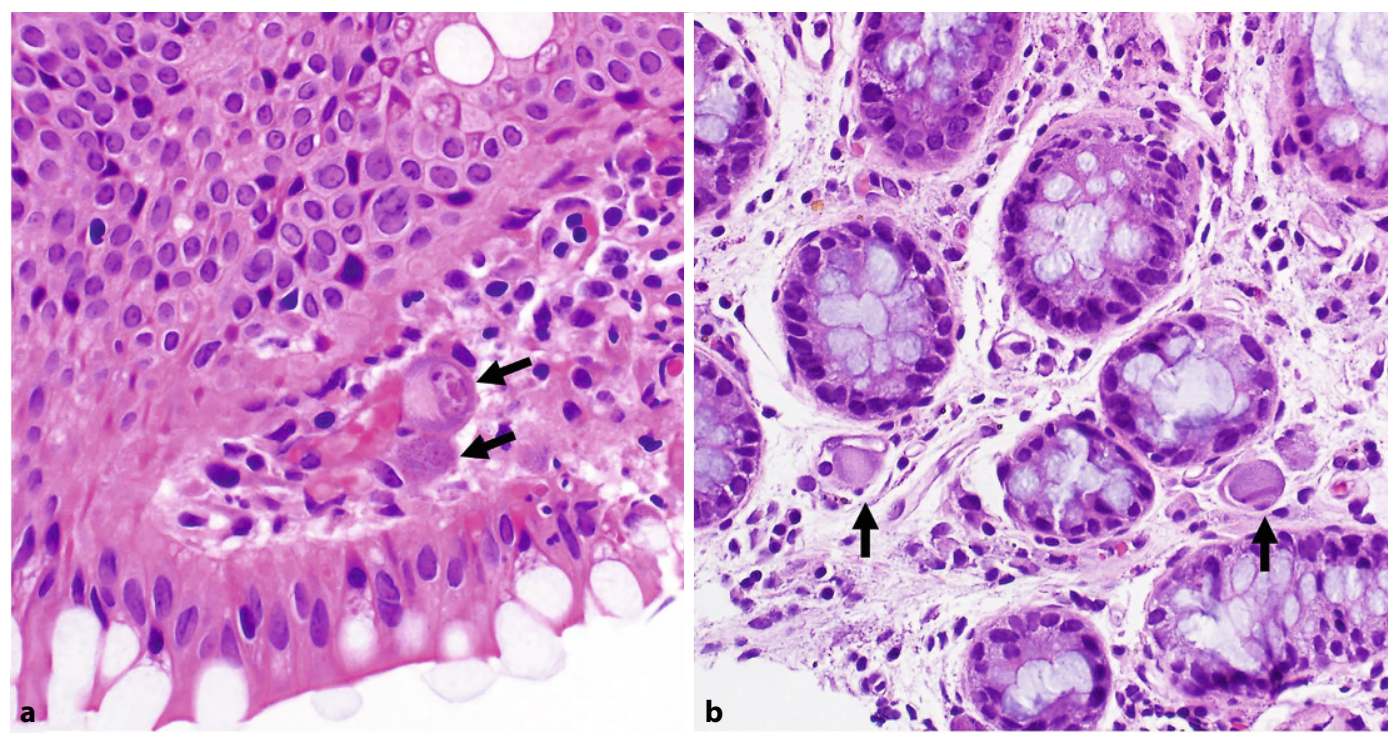

Fig. 1 Cytomegalovirus (CMV)-infected cells (H\&E stain). a Two infected cells (arrows) are seen: one exhibits enlargement and the classic glassy nuclear inclusion, and another displays subtler features with coarse, eosinophilic cytoplasmic inclusions. b Immunosuppressed patients may not mount much of an inflammatory response to CMV infection as seen in this biopsy. Two enlarged, CMV-infected endothelial cells are present (arrows). H\&E hematoxylin and eosin

\section{Viral colitis}

\section{Cytomegalovirus}

Cytomegalovirus (CMV) is of particular concern in chronic idiopathic inflammatory bowel disease (IBD) and transplant patients. Corticosteroid-dependent IBD patients have a higher risk for CMV than those taking biologic agents [1]. Moreover, as there is a high risk of colectomy in treatment-refractory IBD patients presenting with severe flare, it is critical to search for CMV in their biopsies. Identifying CMV allows for a treatable, alternative cause of the symptoms besides refractory $\mathrm{IBD}$, which may allow the patient to avoid surgery.

Microscopically, infected colonic biopsies may show ulcer tissue or severely active colitis with viral inclusions. CMV-infected cells are enlarged and can have both nuclear and cytoplasmic inclusions. The nuclei classically exhibit eosinophilic, glassy inclusions surrounded by a halo of empty space and then rimmed with condensed chromatin, imparting an "owl's eye" appearance. The cytoplasmic inclusions are brightly eosinophilic granules (- Fig. 1). The viral inclusions can be seen in endothelial cells, stromal cells, epithelial cells, and macrophages. Intact, infected colonic mucosa may show crypt abscesses or apoptotic bodies.

Although CMV inclusions can be recognized on routine hematoxylin and eosin (H\&E) staining, several issues may pose challenges to their identification. It can be difficult to see viral inclusions in the cellular background of heavily inflamed tissue, particularly in IBD patients presenting with flare. The opposite can also be true. Pathologists usually scan slides on low-power magnification for foci of inflammation to indicate where to look on higher-power magnification for abnormalities, such as viral inclusions. Transplant patients' biopsies, however, may lack an inflammatory response to infection and may appear normal, causing pathologists to overlook virally infected cells (• Table 1). Moreover, clinicians do not always inform pathologists that the biopsies are from immunosuppressed patients, increasing this risk of misdiagnosis. Other difficulties in diagnosing CMV on H\&E include inadequacy of sampling and morphologic mimicry. CMV-infected cells may be quite focal and missed if only a few sites are sampled or only a few sections of tissue are examined [2]. Ganglion cells or reactive myofibroblasts in ulcers can mimic the appearance of viral inclusions. Finally, infected cells may not display the classic morphology of CMV [3]. IHC can aid in the identification of CMV and is particularly important to utilize in high-risk settings such as steroiddependent IBD patients and immunosuppressed transplant patients suspected of CMV infection.

There has been controversy over whether CMV inclusions in biopsies represent true pathogens or "innocent bystanders" in the background of severe IBD.
One study considered clinical improvement upon antiviral treatment to indicate that the virus was pathogenic. They found that IBD patients with 5 or more CMVpositive cells in a single biopsy fragment benefited from antiviral therapy and had a reduced risk of surgery. This suggests that the burden of viral inclusions signifies whether CMV is causative of the patient's symptoms or whether it was a bystander in severe IBD [4]. Another report, however, found that patients with 5 or more CMVpositive cells per biopsy section were at a higher risk of colectomy than those with less than 5, despite antiviral therapy [5]. As CMV was associated with higher scores of histologic inflammatory activity, these authors considered the presence of CMV to be an indicator of severe inflammation. Nevertheless, because CMV infection is a treatable reason to avoid colectomy, current clinical guidelines from the US and the UK call for biopsies to be evaluated for CMV by H\&E and IHC in patients with severe flares.

Finally, pathologists may question whether finding rare CMV cells on H\&E is clinically important or whether positive cells on IHC without an H\&E correlate should be reported. Regarding the latter, CMV IHC can certainly cause spurious focal staining with certain cells, such as plasma cells. This is of dubious significance. On the other hand, the presence of IHCpositive cells matching the size and shape of true inclusions, but without H\&E correlates, can pose challenges as to whether 
Table 1 List of organisms that may not be surrounded by an inflammatory response

Infectious organisms not always associated with a tissue inflammatory response

Cytomegalovirus (CMV)

Adenovirus (ADV)

Schistosoma eggs

Aspergillosis

Bacterial infections

Strongyloidiasis

this is clinically actionable. A small study showed that the majority of patients with CMV inclusions identified by IHC alone did improve with antiviral therapy [3]. As to the clinical significance of rare CMV cells seen on $\mathrm{H} \& \mathrm{E}$, this may be condition dependent. One report evaluated IBD, human immunodeficiency virus (HIV), and bone marrow transplant patients with rare CMV inclusions. As a single-institution study, it revealed that IBD patients with rare $C M V$ in their practice were likely to receive treatment if the blood polymerase chain reaction $(P C R)$ result was also positive for CMV, whereas HIV and transplant patients with rare inclusions would receive treatment regardless of the blood PCR result [6].

\section{Adenovirus}

Adenoviruses (ADV) are nonenveloped, double-stranded DNA viruses that can cause clinically significant diarrhea. Gastrointestinal (GI) ADV infections have been described mainly in HIV, solid organ transplantation, intestinal transplantation, and hematopoietic stem cell transplant (HSCT) patients [7]. Pediatric patients are particularly prone to infection, with $32 \%$ of pediatric HSCT recipients affected compared to $6 \%$ of adult HSCT patients [8]. In fact, after CMV, ADV is the most frequent DNA virus to infect pediatric patients in the early phase of allogenic HSCT [9]. Mortality rates of disseminated infection are as high as $26 \%$, but anti-viral treatment with proven efficacy against ADV is lacking [10].

The infection causes nuclear inclusions that can be subtle on microscopy due to minimal nuclear changes and little inflammatory response. Unlike CMV, which causes both nuclear and cytoplasmic in-

\begin{tabular}{|c|c|c|}
\hline & Adenovirus & Cytomegalovirus \\
\hline $\begin{array}{l}\text { Location of } \\
\text { inclusions }\end{array}$ & Nucleus only & Nucleus and cytoplasm \\
\hline $\begin{array}{l}\text { Types of cells } \\
\text { infected }\end{array}$ & Epithelium, especially surface & Endothelial, stromal, epithelial cells \\
\hline \multirow{7}{*}{$\begin{array}{l}\text { Cytopathic } \\
\text { effect }\end{array}$} & Minimal to mild nuclear enlargement & Marked enlargement of the cells \\
\hline & $\begin{array}{l}\text { Smudgy nuclear inclusion with com- } \\
\text { pressed rim of darker chromatin }\end{array}$ & $\begin{array}{l}\text { Owl-eye inclusion: central, dense } \\
\text { eosinophilic inclusion surrounded } \\
\text { by a halo of empty space and then } \\
\text { rimmed by chromatin }\end{array}$ \\
\hline & & Coarse cytoplasmic inclusions \\
\hline & $\begin{array}{l}\text { Infected goblet cells with crescent- } \\
\text { shaped nucleus indented by cytoplas- } \\
\text { mic mucin }\end{array}$ & \multirow[t]{4}{*}{ Apoptotic bodies } \\
\hline & Apoptotic bodies & \\
\hline & Disorganized surface epithelium & \\
\hline & If small bowel: slightly blunted villi & \\
\hline $\begin{array}{l}\text { Inflammatory } \\
\text { response }\end{array}$ & $\begin{array}{l}\text { Ranges from minimal inflammatory } \\
\text { response to mild active or chronic } \\
\text { inflammation }\end{array}$ & $\begin{array}{l}\text { Ranges from minimal inflammatory } \\
\text { response to ulcer }\end{array}$ \\
\hline
\end{tabular}

clusions, ADV affects only the nucleus and changes are characterized by a smudgy or glassy-appearing inclusion within the nucleus, minimally enlarging it, and rimmed by a compressed ring of darker chromatin (- Table 2). Infected goblet cells may have a slightly enlarged, crescent-shaped nucleus due to indentation by the nearby cytoplasmic mucin vacuoles (• Fig. 2). The epithelium may take on a subtly disorganized and regenerative appearance due to slight enlargement of nuclei by the inclusions and depleted mucin of the affected cells. Apoptotic bodies can be seen in association with the infected cells; as such, in HSCT patients' colonic biopsies, graft versus host disease (GVHD) may not be confidently diagnosed in the presence of apoptosis near viral inclusions. Immunohistochemistry is helpful for highlighting the inclusions. Coinfection with CMV and other pathogens can occur [7].

\section{Bacterial colitis}

Biopsies for acute bacterial colitis are infrequent specimens, especially given the availability of PCR testing for gastrointestinal pathogens. Patients may be biopsied if they have severe or unusual clinical presentations or if they have prolonged symptoms that do not improve with treatment. The morphologic features seen in biopsy depend on the timing of the biopsy procedure in relation to the duration of the patient's symptoms. If biopsies are taken within the first week of symptoms, the classic "acute self-limited colitis" pattern of neutrophilic inflammation with cryptitis and crypt abscesses predominates. If the biopsy is taken later in the course of the illness, plasma cells and eosinophils increase in the lamina propria. Infectious colitis tends to be patchy rather than diffuse in distribution. Certain infectious agents have a propensity for affecting specific segments of the colon. Campylobacter, Yersinia, tuberculosis, and Salmonella have a predilection for the proximal colon, whereas gonorrhea, syphilis, and lymphogranuloma venereum (LGV) tend to affect the distal colon. The histology of bacterial infection varies depending on the organism and can range from minimal inflammation, active colitis without crypt architectural distortion, to features mimicking inflammatory bowel disease (IBD). Granulomas, histiocytic collections, pseudomembranous colitis, and ischemic change can also occur with specific bacterial entities.

\section{Pseudomembranous colitis}

Pseudomembranous colitis can be caused by infectious agents such as Clostrid- 

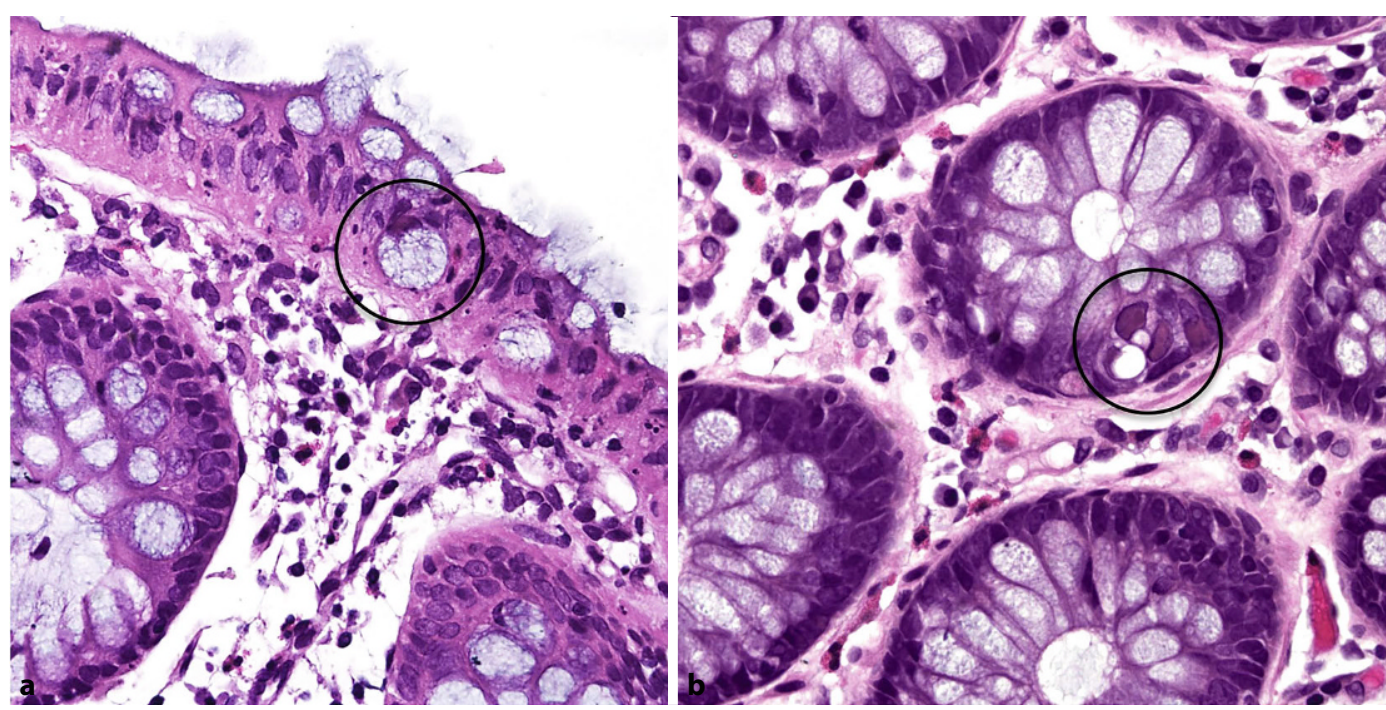

Fig. $2 \triangleleft$ Adenovirus (ADV) inclusions (H\&E stain).

a The nucleus of an infected goblet cell (circled) is mildly enlarged and hyperchromatic. It has an indented, crescent-shaped nucleus because of compression against the mucin vacuole. b A cluster of infected crypt epithelial cells (circled) has a slightly disorganized, "jumbled up" appearance because of loss of usual basal nuclear polarity. The nuclei are slightly enlarged and have a smudgy inclusion. H\&E hematoxylin and eosin. (Courtesy of Laura Lamps)
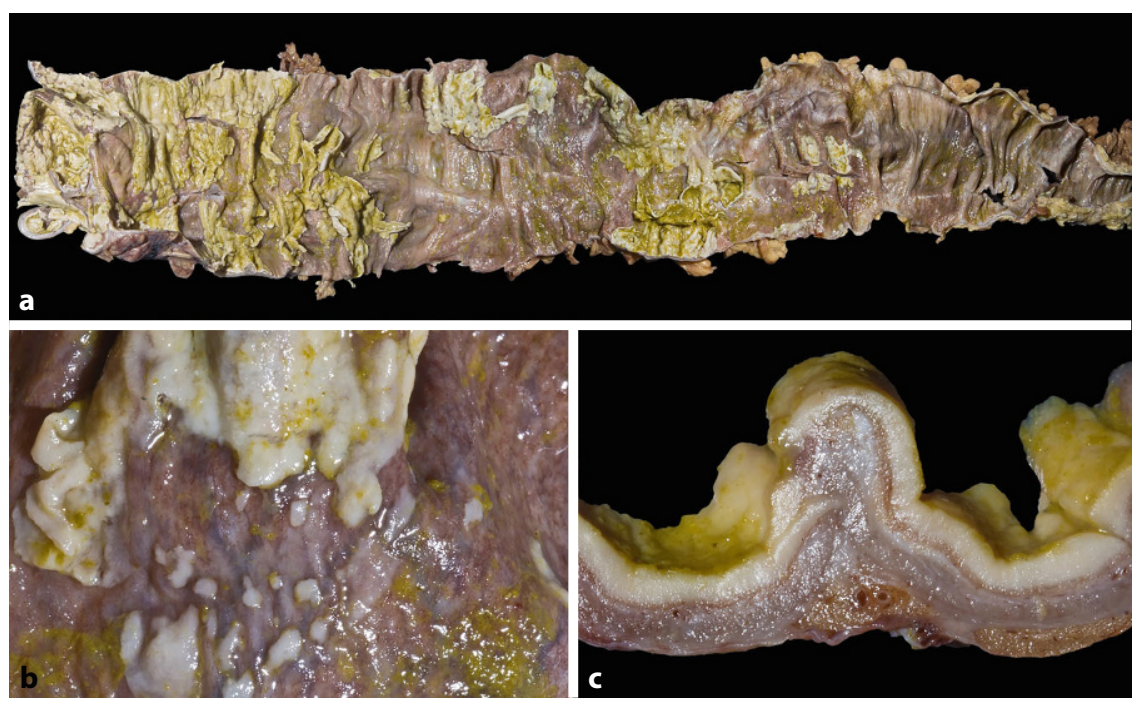

Fig. $3 \Delta$ Pseudomembranous colitis, gross appearance. a-c Pseudomembranes are yellow and white nodules and plaques that have coalesced in some areas. This resection specimen also reveals a dilated bowel with markedly attenuated wall thickness. (Courtesy of Henry Appelman)

ioides difficile, Shigella, Escherichia coli 0157:H7, and other Shiga toxin-producing E coli. Watery diarrhea in the setting of antibiotic use is the classic clinical scenario for $C$. difficile infection. Severe disease can lead to fulminant colitis with shock or toxic megacolon. The diagnosis in a patient experiencing acute diarrhea can be established via positive molecular, culture, or immunoassay studies. Diffuse yellow plaques and nodules can be seen on endoscopy in pseudomembranous colitis (- Fig. 3), but some patients may present without pseudomembranes and merely show erythema and friability. These atypical endoscopic manifestations still have the characteristic histologic findings.
Histologically, pseudomembranous colitis has a mix of inflammatory and ischemic features. Fibrin, neutrophils, necrotic epithelium, and mucus make up the inflammatory exudates of the pseudomembranes. These originate from necrotic crypts and protrude into the lumen with the appearance of a volcanic eruption. The surface epithelium demonstrates an ischemic appearance, characterized by attenuated epithelium lining the crypts ( $\bullet$ Fig. 4). The adjacent epithelium may show active colitis or hemorrhage. The same organisms that can cause pseudomembranous colitis can also cause a predominantly ischemic appearance that can be indistinguishable from noninfectious causes of ischemia in the colon.

\section{Salmonellosis}

There are typhoid and nontyphoid Salmonella species. Nontyphoid Salmonella include S. enteritidis and S. typhimurium; these classically cause the acute colitis pattern, although crypt distortion and plasma cells may be seen as well (- Fig. 5a). S. typhi and S. paratyphi cause typhoid fever. Patients present with acute-onset abdominal pain and fever, followed by watery diarrhea that progresses to bloody diarrhea. The terminal ileum and right colon are most affected. Endoscopically, prominent, nodular Peyer patches can be seen in the terminal ileum. Aphthous ulcers mimicking Crohn's disease occur when the mucosa overlying Peyer patches ulcerates. In advanced cases, deep, discoid, or linear ulcers form and can progress to perforation [11].

The microscopic findings in typhoid fever differ from the classic acute colitis pattern of bacterial infection. Ulcers along the Peyer patches show lymphocytes, plasma cells, and histiocytes, along with necrosis. These histiocytes, also referred to as "typhoid cells" or "Mallory cells," are the main cell type. The classic typhoid fever lesion is the ulcerated Peyer patch, with numerous macrophages containing phagocytized bacteria and red blood cells. 


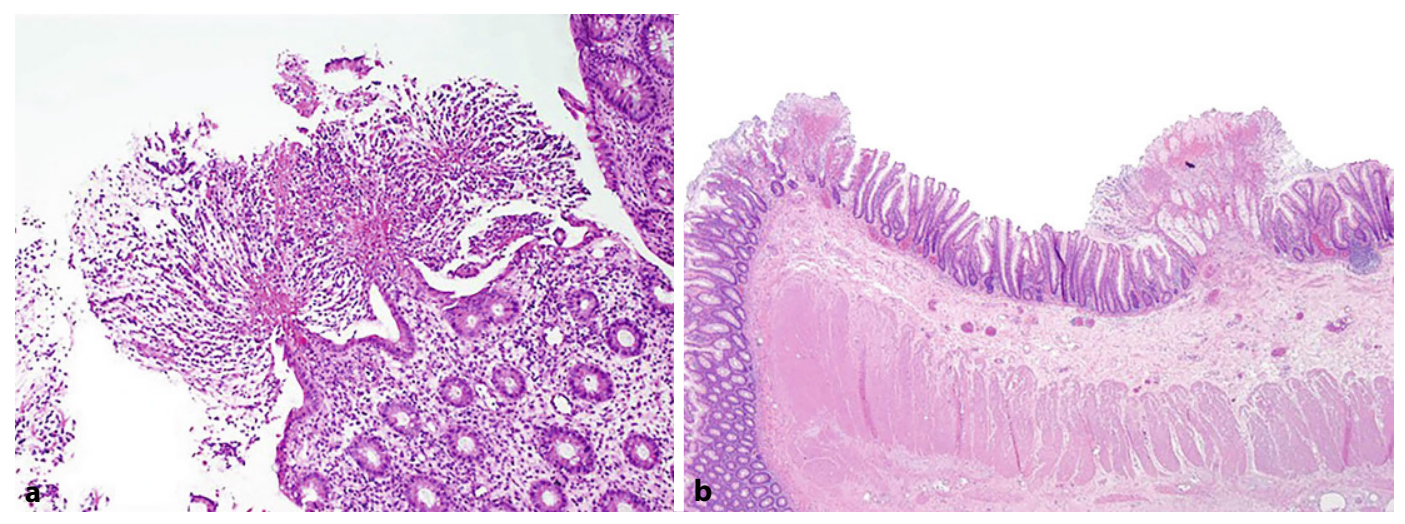

Fig. 4 \ Pseudomembranous colitis, microscopic appearance. a This biopsy specimen shows a volcano-like eruption of fibrin and inflammatory cells. (Courtesy of Laura Lamps). b A resection specimen shows epithelial attenuation and damage underneath the mushroom-like pseudomembranes intervened by areas of intact mucosa. (Courtesy of Henry Appelman)
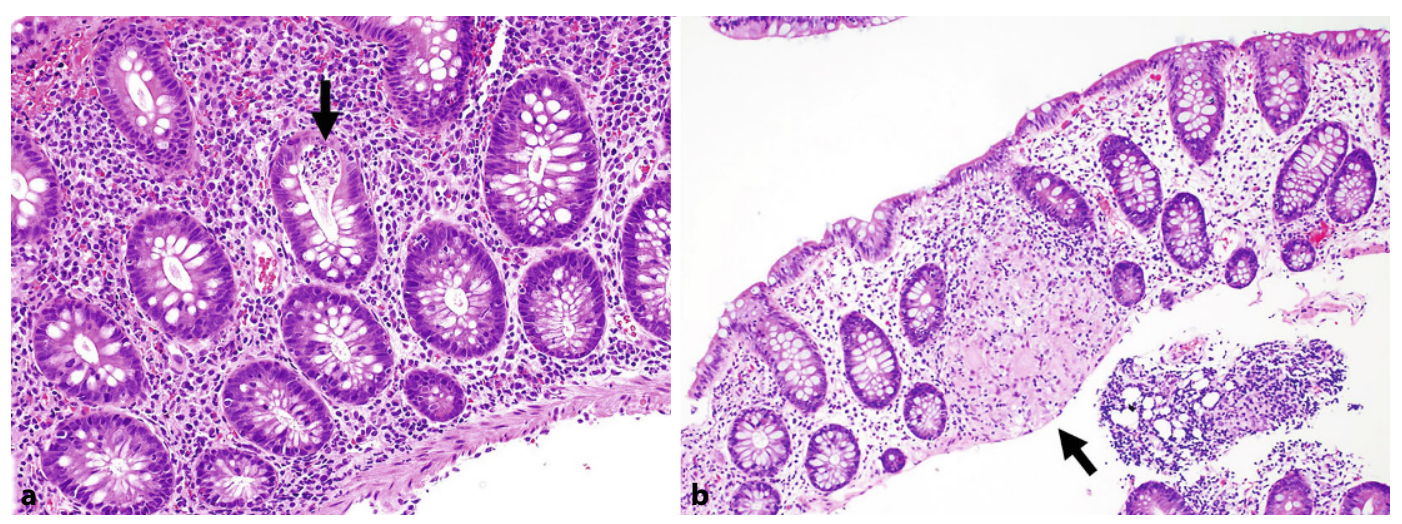

Fig. $5 \Delta$ Examples of bacterial infection (H\&E stain). a A case of nontyphoid Salmonella-induced acute colitis shows intact crypt architecture. A neutrophilic crypt abscess is seen (arrow). Plasma cells may be prominent in the lamina propria if the biopsy is taken later in the course of infection. b Yersinia can cause granuloma formation (arrow), making distinction from Crohn's disease challenging. H\&E hematoxylin and eosin. (Courtesy of Laura Lamps)
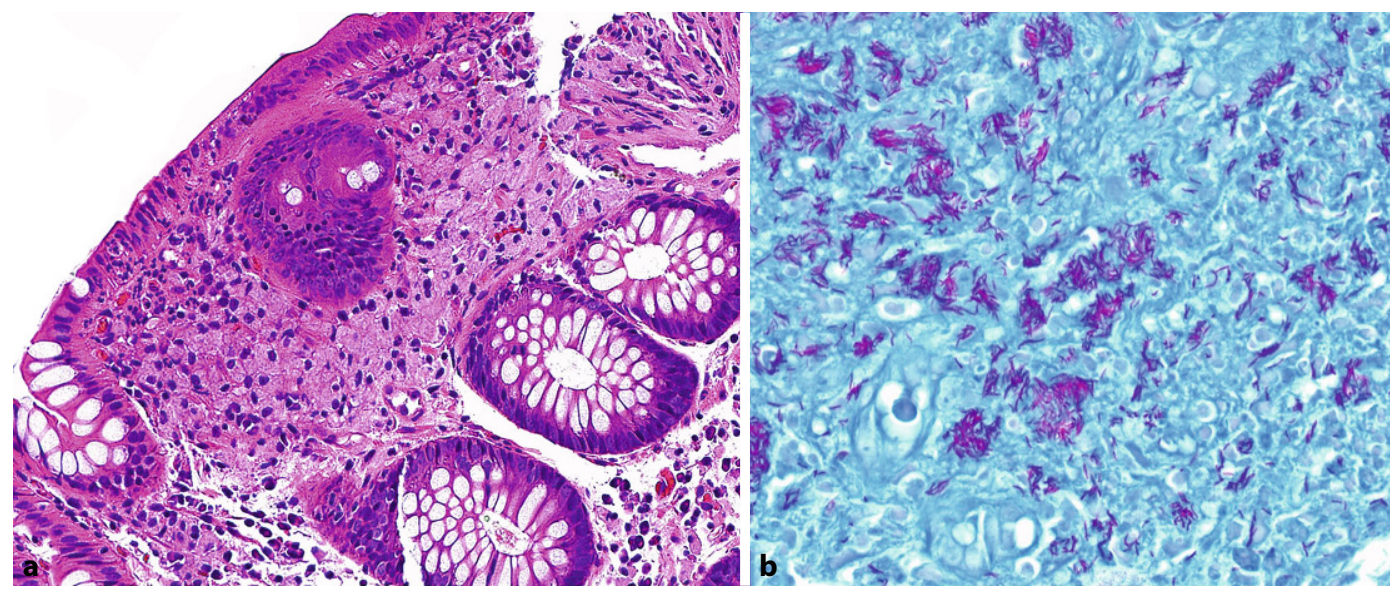

Fig. $6 \triangleleft$ Mycobacterium avium-intracellulare complex (MAI) infection (H\&E stain). a The lamina propria shows collections of macrophages filled with the organisms. b Ziehl-Neelsen stain highlights the acid fast bacilli. H\&E hematoxylin and eosin

\section{Yersiniosis}

Y. enterocolitica and Y. pseudotuberculosis are the main species that cause enteric infections in humans. Transmission is via contaminated food and water. Patients with iron overload have an increased risk for infection. Yersinia can affect the appendix, ileum, colon, mesentery, and lymph nodes. It can mimic Crohn's disease because of the organism's predilection for the right colon and its ability to cause aphthous ulcers, granulomas, and transmural inflammatory involvement with lymphoid aggregates (• Fig. 5b). Both acute colitis and granulomas may be seen on microscopy, although granulomas with neutrophilic abscesses are more associated with Y. pseudotuberculosis. PCR may be necessary to assist in distinguishing between yersiniosis and Crohn's disease [12]. 
Table 3 Select infections that can clinically mimic colon cancer

Can mimic colon cancer

Histoplasma capsulatum

Chlamydia trachomatis (LGV)

Treponema pallidum

Basidiobolus ranarum

Granulomas may be seen more in ileocecal involvement than in the rest of the colon, where the disease can take on a nonspecific, inflammatory appearance.

\section{Mycobacteria}

Abdominal tuberculosis (TB), caused by Mycobacterium tuberculosis, accounts for only $5 \%$ of TB cases in the world. The most common $\mathrm{Gl}$ site affected is the ileocecal valve, followed by jejunum and colon [13]. Intestinal TB can be confused with Crohn's disease because of the anatomic sites involved, along with segmental distribution of infection and stricture formation [14]. Histologic features include submucosal, confluent, necrotizing granulomas. Older lesions are hyalinized and can calcify. Acid fast stains such as Ziehl-Neelsen may demonstrate the presence of the bacteria and $\mathrm{PCR}$ is confirmatory. Mycobacterium avium-intracellulare complex (MAI) most commonly affects immunocompromised patients, particularly causing systemic bacterial infection in acquired immunodeficiency syndrome (AIDS) patients. The colon can be involved, although less commonly than the small bowel. In immunocompromised patients, the colonic lamina propria exhibits sheets of macrophages filled with acid fast bacilli (- Fig. 6). On the other hand, granuloma formation can be seen in immunocompetent patients [15]. The organisms are not only positive on stains for acid fast bacteria but also on periodic acid-Schiff (PAS) staining and Grocott methenamine silver (GMS) [16].

\section{Sexually transmitted proctocolitis}

LGV is caused by the obligate intracellular bacterium Chlamydia trachomatis, serovars L1, L2, L3. These serovars infect macrophages and monocytes, which take

Table 4 Select infections that can mimic chronic idiopathic inflammatory bowel disease (IBD)

\begin{tabular}{|l|l|}
\hline Can mimic IBD & Features to help distinguish from IBD \\
\hline E. histolytica & $\begin{array}{l}\text { Identify trophozoite: up to } 40 \mu \mathrm{m} \text {, abundant foamy or } \\
\text { vacuolated cytoplasm, ingested RBCs, nuclear features }\end{array}$ \\
\hline Yersiniosis & May need PCR to distinguish \\
\hline Strongyloidiasis & Presence of larvae and adult worms \\
\hline Basidiobolus ranarum & GMS, hyphae resembling "crinkled cellophane" \\
\cline { 2 - 2 } & Splendore-Hoeppli phenomenon \\
\hline $\begin{array}{l}\text { Sexually transmitted proctocolitis } \\
\text { (C. trachomatis (LGV), T. pallidum) }\end{array}$ & $\begin{array}{l}\text { An overall intact crypt architecture as well as infrequent } \\
\text { Paneth cells and eosinophils }\end{array}$ \\
\hline Mycobacterium tuberculosis & Caseating granulomas, acid fast stain, PCR \\
\hline Cryptococcus neoformans & Perform special stains, GMS, mucicarmine \\
\hline Schistosomiasis & See $\mathbf{0}$ Table 5 \\
\hline $\begin{array}{l}\text { RBC red blood cell, PCR polymerase chain rection, GMS Grocott methenamine silver, LGV lym- } \\
\text { phogranuloma venereum }\end{array}$ & \\
\hline
\end{tabular}

the organism to the lymph nodes and may disseminate the disease. Although anal intercourse is a common cause of LGV proctitis, rectal disease can also occur via lymphatic spread of the organism from the vagina. HIV patients are particularly at risk; however, HIV positivity is not necessary to contract sexually transmitted proctocolitis [17]. Coinfection with other infectious agents, such as syphilis and/or gonorrhea, is frequent. Diagnosis is confirmed by rectal swab for $C$. trachomatis nucleic acid amplification, culture, or direct immunofluorescence testing. Three disease stages occur in LGV. Regional lymph node involvement and anorectal manifestations occur in the second stage. This includes inflammatory masses, proctitis, and hemorrhagic proctocolitis (- Table 3 ). The anorectum is most commonly affected, but more proximal involvement can occur [18]. Without treatment, the disease progresses to scarring with stricture and fistula formation, representing the late, tertiary stage.

The histologic features of LGV proctitis are mild to moderate active inflammation and lamina propria plasmacytosis. The ulcers, granulomas, fibrosis, and strictures that may also be seen with this disease can make distinction from IBD difficult. Unlike $\mathrm{IBD}$, however, LGV proctitis tends to have mostly intact crypt architecture, a lack of Paneth cells, and fewer eosinophils than IBD ([19]; - Table 4). Early LGV proctitis may not show granulomas; neutrophilic cryptitis and crypt abscesses are present and pseudomembranes can form if the inflammation is severe [20]. Soon after, how- ever, lymphoplasmacytic and histiocytic inflammation predominates, with plasmacell-rich inflammation in the lamina propria and submucosa (- Fig. 7). Swollen endothelial cells and perivascular plasma cell cuffing can also be seen [19]. An RNA in situ hybridization test for C. trachomatis exists for formalin-fixed paraffin-embedded tissue samples. Positivity consists of punctate, dot-like staining in the cytoplasm of affected cells. It is reported to have $84 \%$ sensitivity and $100 \%$ specificity [21].

\section{Syphilis}

Syphilis is caused by the spirochete Treponema pallidum. The anorectal area is the most affected portion of the lower Gl tract. Initial screening is with a nontreponemal test such as rapid plasma reagin, and, if reactive, followed by a treponemal test, such as fluorescent treponemal antibody absorption. The diagnosis can also be made on anorectal mucosal or ulcer swab samples via PCR [17]. Like LGV, syphilitic proctitis can clinically mimic IBD or rectal cancer. The microscopic appearance is similar to LGV: the mucosa exhibits intense lamina propria plasmacytosis with mostly intact crypt architecture and occasional granulomas (- Fig. 8). Not all cases may show abundant plasma cells, however. Additional patterns reported of lower Gl syphilis include histiocytic-predominant infiltration of the lamina propria along with loose granulomas and a lymphoma-like pattern with atypical appearing lymphocytes [22]. Notably, plasma 

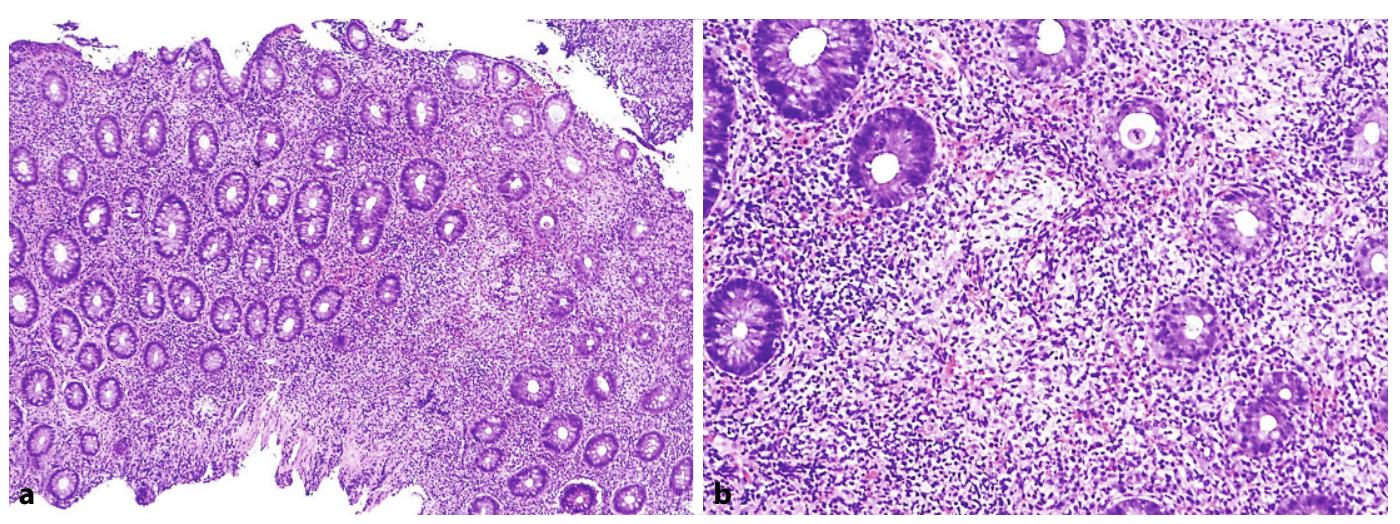

Fig. $7 \triangleleft$ Lymphogranuloma venereum (LGV) proctitis (H\&E stain). a The lamina propria is packed with plasma cells and crypt dropout is seen. b Prominent clusters of histiocytes are present in the lamina propria. H\&E hematoxylin and eosin
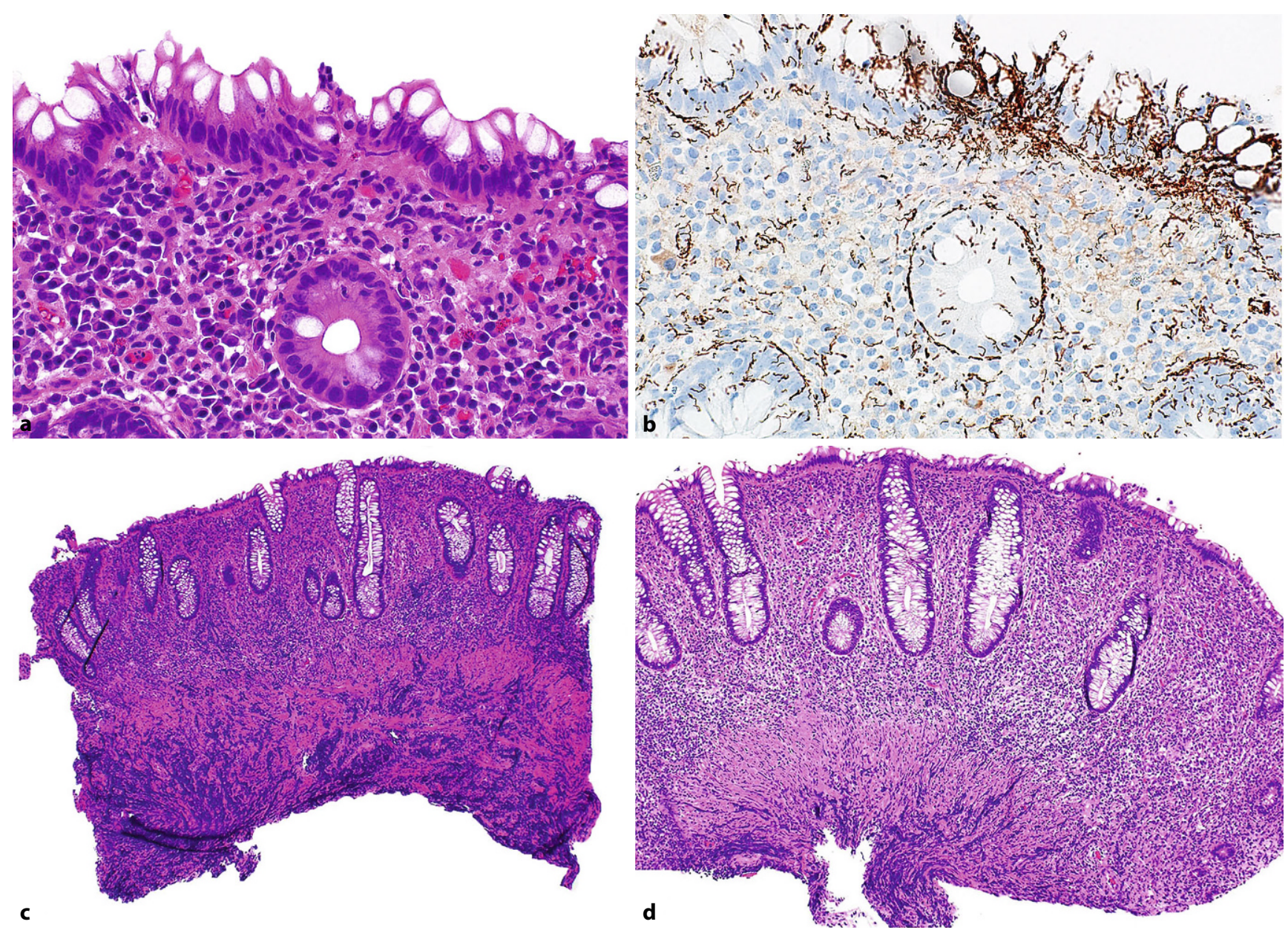

Fig. $8 \Delta$ Syphilitic proctitis (H\&E stain). a Mild active inflammation is present at the surface of this biopsy. Plasma cells are prominent in the lamina propria. $\mathrm{b}$ Immunohistochemistry for T. pallidum highlights numerous organisms. c Intense plasmacytosis involves the entire mucosa and even the submucosa in this example of syphilis. $\mathbf{d}$ Another case demonstrates prominent clusters of histiocytes. $H \& E$ hematoxylin and eosin

cells may also be seen cuffing submucosal nerves. IHC for T. pallidum highlights the organisms in affected areas such as the epithelium and around vessels. Spirochetosis due to Brachyspira spp. can also be positive for this stain and should not be misinterpreted as syphilis [23]. Histologically, the Brachyspira organisms are present as an accentuated brush border on top of the colonocytes with minimal inflammatory response. Whether or not Brachyspira spp. cause diarrhea is debatable.

\section{Fungal colitis}

Fungal infections of the lower Gl tract are uncommon and often occur in immunocompromised hosts. Identification methods such as molecular assays and culture are important in confirming the type of 

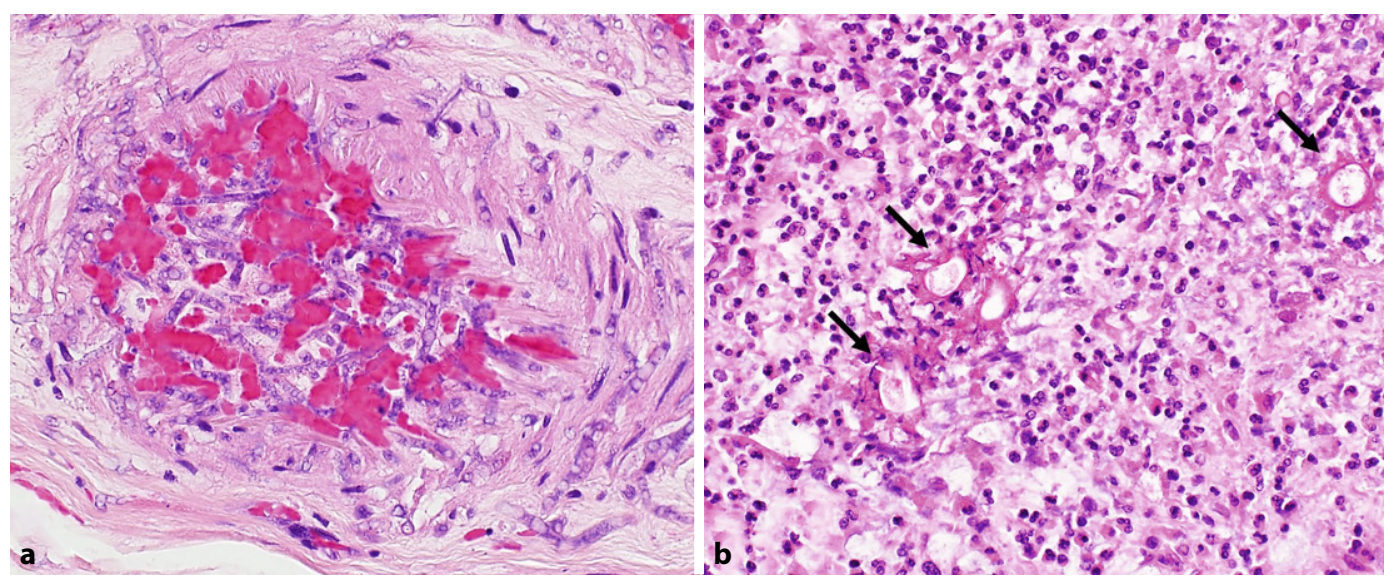

Fig. 94 Aspergillosis and basidiobolomycosis (H\&E stain). a Septate hyphae with parallel walls and acute-angle branching of Aspergillus are seen emanating out of a vessel. b Basidiobolus ranarum exhibits the Splendore-Hoeppli reaction (arrows). H\&E hematoxylin and eosin. (Courtesy of Laura Lamps)
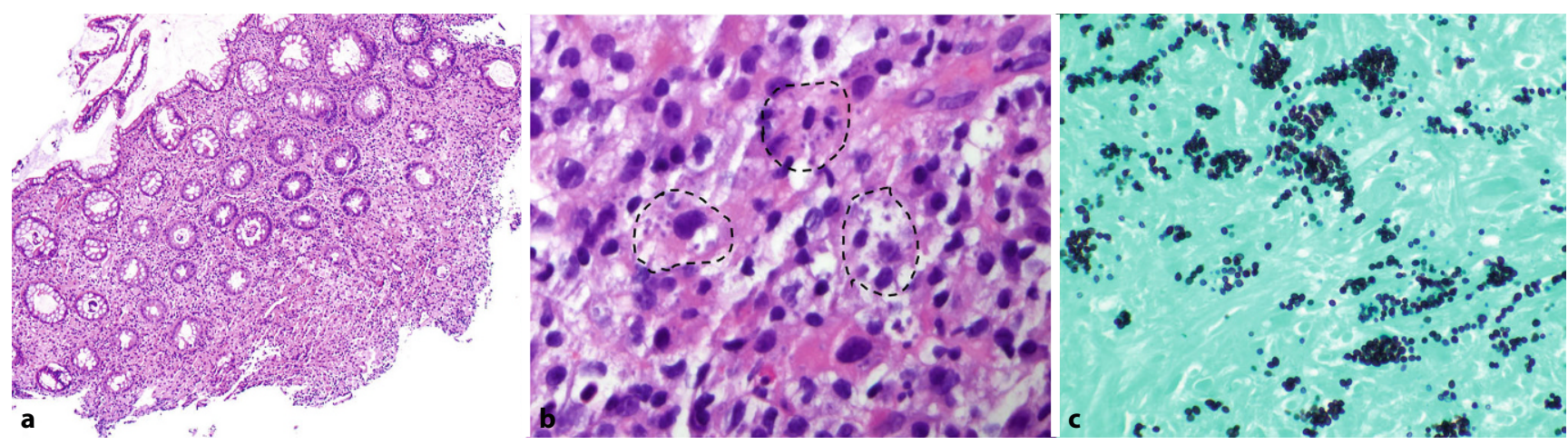

Fig. $10 \Delta$ Histoplasmosis. a In this case (H\&E stain), the lamina propria is expanded by sheets of histiocytes at the base of the colonic mucosa. $\mathbf{b}$ High-power magnification on H\&E stain reveals macrophages (encircled) containing round intracellular yeasts. Each is surrounded by a thin, poorly staining wall resembling a halo.c Grocott methenamine silver special stain highlights the organisms. H\&E hematoxylin and eosin

fungal organism. Although stains such as GMS may be helpful, histopathologic identification is insensitive, especially as fungal forms can swell and change their morphology with necrosis or treatment [24]. As some organisms are resistant to, or may require a different drug besides, amphotericin $B$ treatment, the final diagnosis of a specific fungus should be deferred to definitive methodologies. Nevertheless, because of the time it takes for other laboratory methods to identify fungi, pathologists may be asked to attempt a preliminary diagnosis on histology.

\section{Candidiasis}

Colonic candidiasis occurs exclusively in immunocompromised patients and accounts for $20 \%$ of Gl candidiasis. Colon is the third most common Gl organ to be involved, following esophagus and stomach [25]. Gross findings include mucosal flecks that resemble pseudomembranous colitis, irregular ulcers, segmental infarcts, and masses. Microscopically, the organisms display a mix of budding yeasts, pseudohyphae, and occasional septate hyphae. They may involve the superficial mucosa and submucosa, elicit an inflammatory mass, or cause transmural infarcts with extensive angioinvasion.

\section{Aspergillosis}

Gastrointestinal aspergillosis is often accompanied by lung involvement. Like candidiasis, it also occurs exclusively in immunocompromised patients and can cause infarction and angioinvasion. Gross abnormalities include mucosal flecks resembling pseudomembranous colitis, linear or oval ulcers, and infarcts. Microscopically, the organisms have septate hyphae with parallel walls and exhibit acute angle branching (- Fig. 9a). Angioinvasion is characterized by fibrin thrombi mixed with hyphae that ra- diate out of vessels and extend into surrounding tissues. Hyphae may also be seen embedded in the mucosal surface. The Splendore-Hoeppli phenomenon, in which intensely eosinophilic, proteinaceous deposits of antigen-antibody complexes surround the organisms, can occur. Other fungi can have overlapping features with Aspergillus. Mucor, which only rarely affects the colon, also tends to cause angioinvasion [26]. Unlike Aspergillus, Mucor are pauciseptate and exhibit broad, ribbon-like hyphae with branching at various angles and optically clear centers. Basidiobolus ranarum, like Mucor, is also in the zygomycetes family. It is the causative agent of basidiobolomycosis; most cases are reported from desert regions of the US and the Middle East. This disease can cause severe infection in both immunocompetent and immunosuppressed individuals. The organisms have broad, occasionally septate hyphae with an appearance resembling 

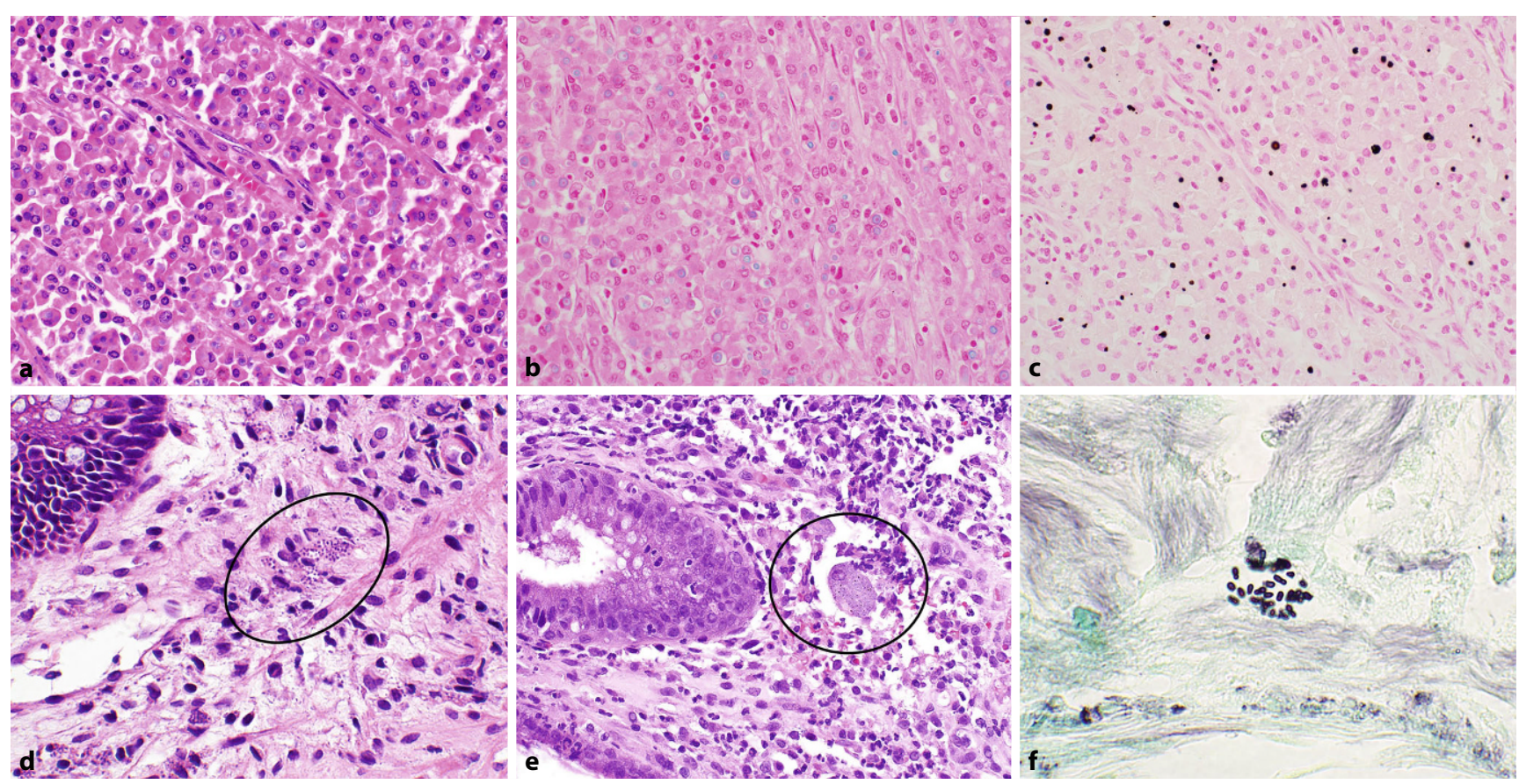

Fig. $11 \Delta$ Potential mimics of histoplasmosis. a-c Malakoplakia. This condition is characterized by sheets of granular histiocytes (von Hansemann cells) containing round, 2-10 $\mu \mathrm{m}$ targetoid concretions (Michaelis-Gutmann bodies) on H\&E. They are highlighted on iron stain (b) and von Kossa stain (c). $\mathbf{d}$ Leishmania donovani (encircled in this H\&E stain) resemble Histoplasma organisms, but are negative on Grocott methenamine silver (GMS). e Talormyces marneffei (encircled in this $H \& E$ stain), like $H$. capsulatum, are intracellular and similar in size. (Courtesy of Laura Lamps). $\mathbf{f}$. marneffei GMS special stain is pictured here, resembling pill capsules because of their midline septae. $H \& E$ hematoxylin and eosin

crinkled cellophane [27]. The organisms are typically surrounded by a striking Splendore-Hoeppli reaction, which occurs less frequently with Mucor ([28, 29];

- Fig. 9b). Unlike Mucor and Aspergillus, the organisms generally tend not to cause angioinvasion. They cause a prominent eosinophilic and granulomatous reaction, with caseating necrosis.

\section{Histoplasmosis}

Histoplasma capsulatum, a soil saprophyte that grows well in bat and avian guano, is prevalent in the Ohio and Mississippi river valleys; it is also endemic in areas of Central and South America. Infection occurs when this soil fungus is inhaled, ingested by macrophages, and spread to the lymph nodes. Gl histoplasmosis can affect both immunocompetent and immunocompromised patients. While isolated $\mathrm{Gl}$ involvement does occur, the $\mathrm{Gl}$ tract is frequently involved in the setting of disseminated disease. The colon, specifically, is involved in over $55 \%$ of Gl histoplasmosis [30]. The most common sites of involvement include right colon, followed by the rectum and descending colon. Gross manifestations include ulcers, erosions, obstructive masses, or polyps [31]. Microscopically, the lamina propria is diffusely expanded by histiocytes with intracellular clusters of small ( $2-5 \mu \mathrm{m})$, narrow-base budding yeasts with thin walls resembling a halo (- Fig. 10). The protoplasm retracts during fixation, resulting in a clear pseudocapsule that appears not to stain. They are positive for GMS and PAS, but may also pick up Ziehl-Neelsen [32]. The organisms can be easily missed within ulcer debris and, rarely, may be extracellular. Granulomas are infrequent in the $\mathrm{Gl}$ tract, occurring in only $8.5 \%$ of cases [30].

Intracellular Candida, particularly C. glabrata, can mimic Histoplasma. C. glabrata tends to have variably sized yeast cells, more frequent buds, and lack the halo seen around Histoplasma in tissue sections. They are positive on Gram stain and are more often extracellular.

Candida elicits a neutrophilic response, whereas Histoplasma manifests with histiocytes or granulomas. Pneumocystis jirovecii and Talormyces marneffei resemble histoplasmosis, but these or- ganisms only rarely involve the colon. Pneumocystis jirovecii organisms are obligate extracellular organisms resembling crushed ping pong balls and lacking buds. T. marneffei infection occurs mostly in Southeast Asia in HIV patients. Like H. capsulatum, T. marneffei organisms are also small, $2-5 \mu \mathrm{m}$, and intracellular within macrophages; however, they do not bud and occasionally have larger forms with midline septa causing the organisms to resemble pill capsules. Other potential mimics of histoplasmosis include leishmaniasis and malakoplakia (0 Fig. 11). Leishmania organisms can also be seen within macrophages; however, they are negative on GMS, positive on Giemsa staining, and can also be extracellular. They are small $(2-4 \mu \mathrm{m})$ round to oval organisms, with a bar-shaped paranuclear kinetoplast [33].

\section{Paracoccidioidomycosis}

Paracoccidioidomycosis, which occurs most commonly in Central and South America, tends to affect the entire colon. Half of cases involving the Gl tract are 


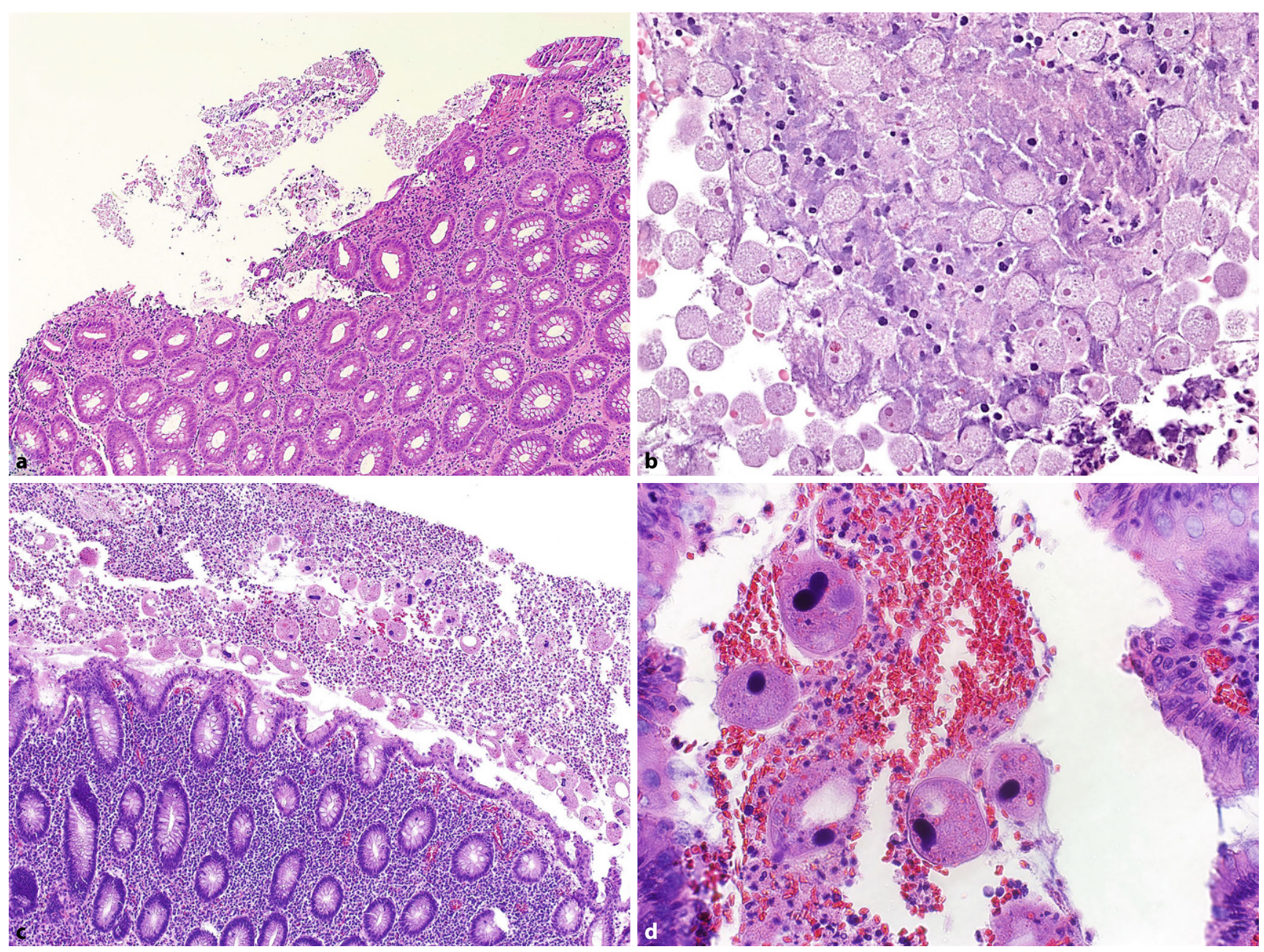

Fig. $12 \Delta$ Amebiasis and balantidiasis (H\&E stain). a In this case of amebiasis, the colonic mucosa shows mild, superficial epithelial damage. The overlying exudate contains the $E$. histolytica trophozoites admixed with fibrin, mucus, and inflammatory cells. b E. histolytica trophozoites are shown here; note the ingested red blood cells. c,d The trophozoite of Balantidium coli is much larger than $E$. histolytica, has a ciliated surface, and a kidney-shaped macronucleus. $H \& E$ hematoxylin and eosin

in the context of disseminated disease, although no risk factors such as an immunocompromised status are associated with it [34]. Patients present with diarrhea and have ulcers, masses, or strictures identified endoscopically. The infection mimics IBD and may also cause malakoplakia [35]. The organisms are variably sized, round, budding yeast cells ranging from 4 to $40 \mu \mathrm{m}$. The classic finding is that of a large mother cell surrounded by budding cells, resembling a ship's wheel. Without this distinctive feature, however, it may be easy to confuse these organisms with other budding yeasts.

\section{Coccidioides immitis}

Coccidioides immitis infection is referred to as Valley fever and only rarely affects the colon $[36,37]$. When it does, it can mimic carcinomatosis by studding the peritoneum. In the tissue, the fungi appear as large, $10-80 \mu \mathrm{m}$ double-walled refractile spherules filled with endospores. The diagnosis should only be made if at least one unequivocal, intact spherule containing endospores is seen [24]. Vague, circular structures resembling empty Coccidioides spherules should not be interpreted as the organism. These can represent cross sections of bulbous parts of other types of fungi such as Aspergillus. The opposite is also true: expelled Coccidioides endospores can mimic other fungi, such as Cryptococcus.

\section{Cryptococcus neoformans}

Cryptococcus neoformans, which is found in pigeon droppings, can cause a granulomatous colitis that simulates Crohn's disease. It can present as a mass, stricture, or abscess, and affect any part of the colon. Most patients are immunocompromised and $\mathrm{Gl}$ involvement is associated with disseminated disease. In fact, $\mathrm{Gl}$ cryptococcosis may be the first manifestation of disseminated disease [38]. Cryptococcus organisms measure $4-7 \mu \mathrm{m}$ and show notable variation in size and frequent budding. They have an area of clearing resembling a soap bubble around the organism. This represents a poorly stained capsule on H\&E sections that, on the other hand, is intensely positive with 


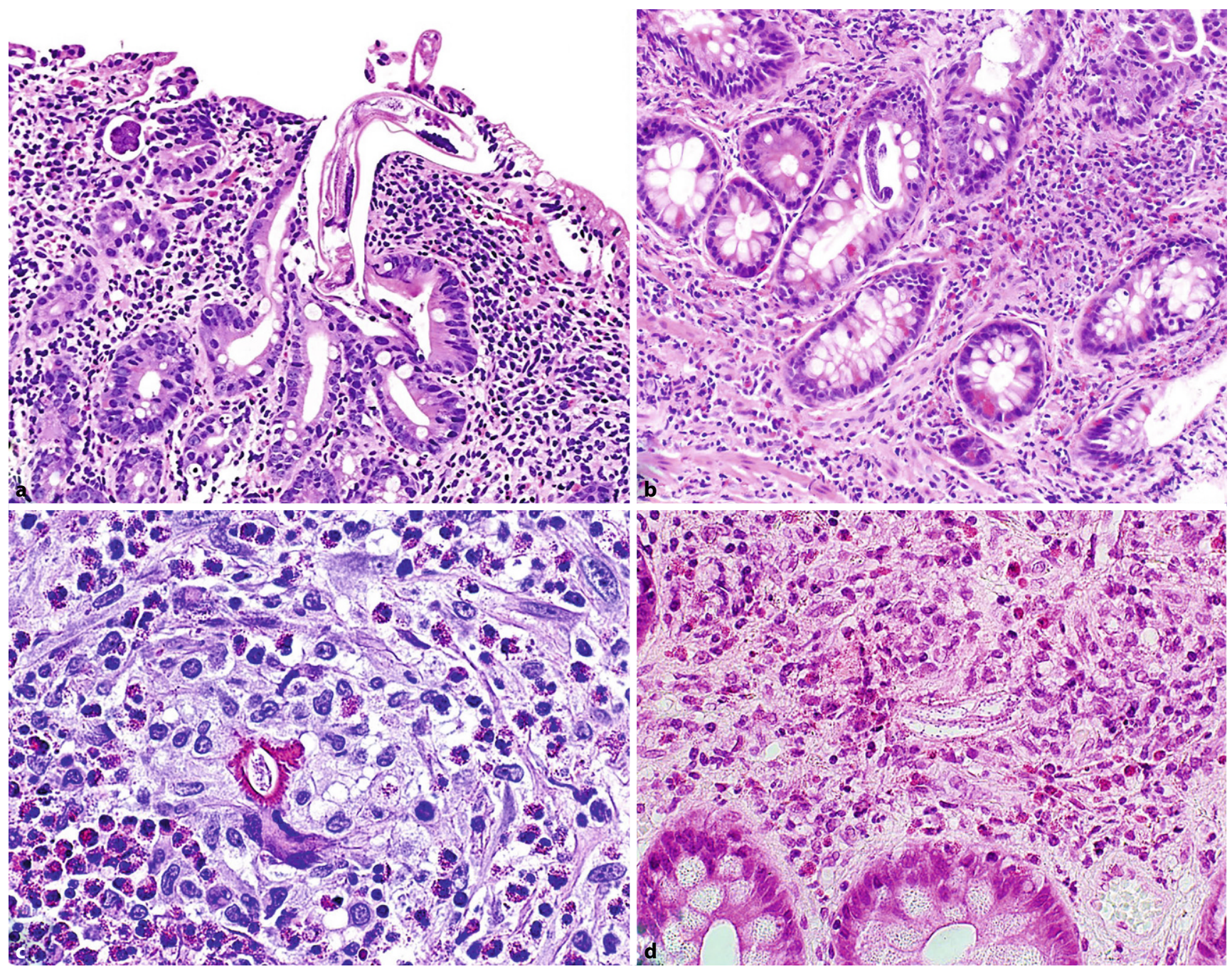

Fig. $13 \Delta$ Strongyloidiasis (H\&E stain). a Adult females have visible internal organs. b Strongyloides stercoralis within a crypt lumen without much inflammation. c Brightly eosinophilic Splendore-Hoeppli phenomenon is seen around a larval form. d Degenerated larvae can be difficult to visualize and may mimic other infectious agents. H\&E hematoxylin and eosin

mucicarmine. Fontana-Masson staining is useful in capsule-deficient Cryptococcus.

\section{Parasitic colitis}

\section{Amebiasis}

The protozoan Entamoeba histolytica causes amebiasis, which is transmitted mainly through fecal-oral spread, but also through anal intercourse. Antigen detection and PCR are sensitive and specific diagnostic tools, but biopsy can raise the first diagnosis $[39,40]$. E. histolytica has trophozoite and cyst forms. The cysts are highly infectious and, unlike trophozoites, can resist both gastric acid and chlorine concentrations used in sewage. When ingested, the cysts reach the ileocecal valve area and release the trophozoites. The trophozoites adhere to colonic epithelial mucin and colonize the large intestine. They also initiate tissue damage by secreting enzymes that lyse cells and eventually give rise to the classic, flask-shaped ulcers. Chronic infection can last for years, be limited to the Gl tract, or spread to other organs, such as liver. The infection can be asymptomatic, cause mild diarrhea, and blood and mucus in the stool, or severe, acute fulminant necrotizing colitis with toxic megacolon and death. Recent literature includes a report of severe acute respiratory syndrome coronavirus 2 (SARS-CoV-2) infection aggravating preexisting amoebic infection, inducing fulminant colitis [41]. Endoscopic findings are nonspecific and show friable and dif- fusely inflamed mucosa. Mass formation, stricture, and perforation can also occur due to amebiasis. The proximal colon is commonly involved, but multiple sites of the colon are usually affected [42].

The classic amoebic lesion is that of a flask-shaped ulcer. As the organisms induce ulcers, they invade both laterally as well as deeply. They undermine intact mucosa, leaving overhanging edges that form the flask-like appearance. Trophozoites are numerous at the edges of the ulcer, undermining the epithelium and causing necrosis and tissue disruption. They are also found in the overlying exudate admixed with fibrin, mucin, and inflammatory cells. Invasion of trophozoites into or through the muscularis propria is a risk factor associated with death in fulminant amebic 
Table 5 Important features to note regarding chronic intestinal schistosomiasis and Crohn's disease

\begin{tabular}{|l|l|l|}
\hline & Chronic intestinal schistosomiasis & Crohn's disease \\
\hline $\begin{array}{l}\text { Common sites of } \\
\text { involvement }\end{array}$ & $\begin{array}{l}\text { Descending colon, sigmoid colon, } \\
\text { rectum }\end{array}$ & Terminal ileum, ascending colon \\
\hline $\begin{array}{l}\text { Peripheral blood } \\
\text { eosinophilia }\end{array}$ & Often not elevated & Often not elevated \\
\hline $\begin{array}{l}\text { Colonoscopic } \\
\text { findings }\end{array}$ & $\begin{array}{l}\text { Granular appearing, yellow mucosa, } \\
\text { polyps, wide-based ulcers }\end{array}$ & $\begin{array}{l}\text { Cobblestoned appearance, longitu- } \\
\text { dinal fissures }\end{array}$ \\
\hline $\begin{array}{l}\text { Helpful histo- } \\
\text { logic features }\end{array}$ & $\begin{array}{l}\text { Submucosal fibrosis, noncaseating } \\
\text { granulomas, multinucleated giant } \\
\text { cells, eggs, pseudopolyps }\end{array}$ & $\begin{array}{l}\text { Granulomas, muscularis mucosa } \\
\text { thickening, pyloric gland metaplasia, } \\
\text { crypt architectural distortion, crypt } \\
\text { abscesses, lymphoid aggregates }\end{array}$ \\
\hline
\end{tabular}

colitis [42]. The organisms measure up to $40 \mu \mathrm{m}$ and have abundant foamy or vacuolated cytoplasm. It is important to see the ingested red blood cells, which helps distinguish E. histolytica from mimics such as macrophages and nonpathogenic amoebas. The amoebae have subtle nuclear features characterized by fine peripheral chromatin and a central karyosome (- Fig. 12). The organisms are intensely PAS positive; IHC for amoeba exists [43]. On the other hand, macrophages are smaller, do not have these distinctive nuclear features, and do not have ingested red blood cells. Another parasite, Balantidium coli, is a large, ciliated protozoan and causes balantidiasis. This disease may cause similar histologic features to E. histolytica, such as flask-shaped ulcers; however, the trophozoite is much larger, ranging from 50 to $200 \mu \mathrm{m}$, with cilia covering its surface. Internal structures include a large, kidney-shaped macronucleus and smaller micronucleus. The spherical cysts are 50 to $70 \mu \mathrm{m}$ (• Fig. 12d).

\section{Strongyloidiasis}

The nematode Strongyloides stercoralis can complete its entire life cycle within a human being. As a result, strongyloidiasis carries the potential for chronic, asymptomatic disease via low levels of autoinfection. Immunocompetent and immunosuppressed persons can be infected alike, and initially become exposed via skin contact with contaminated soil in tropical and subtropical endemic areas. Other, less frequent, modes of transmission include fecal-oral spread and donor-derived infections in transplant recipients [44]. The larvae can reach the small intestine by var- ious means. This includes migrating from the skin to the pulmonary and tracheobronchial system and being swallowed. Maturation to adult worms occurs in the small bowel. Females produce eggs that develop into noninfectious larvae (rhabditiform larvae), which are shed into the stool. Autoinfection occurs when some of the rhabditiform larvae transform into the infective, filariform larvae instead of being excreted [45]. These filariform larvae penetrate the bowel mucosa or the perianal skin and again make their way to the lungs to repeat the cycle of autoinfection.

Clinical diagnosis is difficult due to the lack of specific symptoms and low detection rates of common tests. The low levels of autoinfection can cause persistent, undetected disease over decades, with symptoms that may emerge long after the original exposure. Immunosuppression with even short courses of corticosteroids-regardless of dose, immune status, or remoteness of initial infection-can cause increased autoinfection and more overt symptoms can emerge. The change in immune milieu causes accelerated transformation of the organisms into the infective larval form or increased parasitic burden by means of asexual reproduction. Hyperinfection syndrome refers to the sequelae of accelerated autoinfection. It is often related to a change in immune status and carries a high mortality rate, especially with dissemination of the organisms to organs beyond the Gl tract and lungs.

Serologic testing, stool examination, culture, and PCR are some methods employed for diagnosis. Detection rates, however, may be low unless the patients are experiencing accelerated autoinfection. Colonoscopy may exhibit an appearance and distribution mimicking IBD. Other endoscopic features include erythema, yellow-white nodules, edema, loss of vascular pattern, and ulcers [46]. Therefore, due to the lack of specific symptoms and low sensitivity of common testing modalities, a biopsy identification of the organisms may be the first, and unexpected, way that strongyloidiasis is diagnosed.

Histologically, the organisms may be seen in the small bowel, colon, and stomach. Both worms and eggs can be found in Gl samples in strongyloidiasis. Site-dependent differences exist: as the small bowel is the site of maturation to adults, adult females and eggs are usually visualized in the small bowel rather than the colon, unless the patient is immunosuppressed. Cross sections of the larvae measure 12 to $18 \mu \mathrm{m}$ in diameter [47]. They exhibit a cuticle of $1 \mu \mathrm{m}$ in thickness, surrounding collections of nuclei that measure $1 \mu \mathrm{m}$ each. These nuclei correspond to the alimentary canal of the organism, and, on longitudinal section, are arranged in 1-2 rows measuring $1 \mu \mathrm{m}$ each. Adult females are larger, exhibiting cross-sectional diameters of 30 to $45 \mu \mathrm{m}$ as well as visible internal organs and sharply pointed tails (• Fig. 13). Adults and larvae may be seen occupying crypt lumens without an inflammatory response, whereas the presence of larvae in the lamina propria is usually accompanied by inflammation.

The background bowel mucosa may show varying degrees of eosinophilic and neutrophilic inflammation, crypt distortion, and granulomas, mimicking Crohn's disease. The degree of tissue eosinophilia is related to the burden of parasitic infection [47]. The Splenodore-Hoeppli phenomenon can occur around the organisms [48]. It is important to suspect and search for strongyloidiasis in eosinophilic aggregates, particularly as degenerating larvae can easily be overlooked. One of the differential diagnoses of eosinophilia in the bowel includes idiopathic eosinophilic gastroenteritis, a diagnosis that may be treated with steroids. In the context of overlooked strongyloidiasis, a misdiagnosis of eosinophilic gastroenteritis with ensuing steroid treatment may result in hyperinfection syndrome and fatal consequences. 


\section{Schwerpunkt: Gastrointestinale Pathologie}
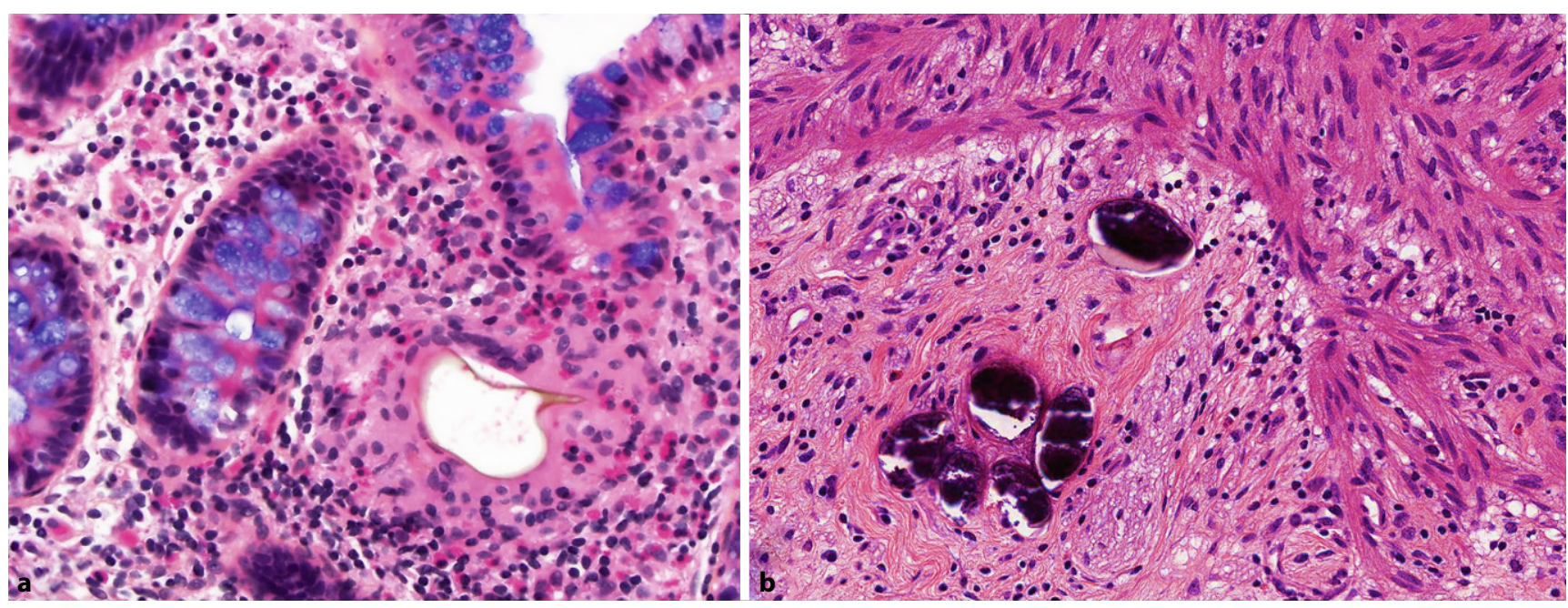

Fig. 14 \ Schistosoma ova. a A multinucleated giant cell is seen surrounding a refractile S. mansoni egg with a lateral spine.

b Calcified Schistosoma eggs are seen with minimal inflammatory response

\section{Schistosomiasis}

Intestinal schistosomiasis (IS) can be a chronic condition acquired first by skin contact with cercarial larvae in contaminated freshwater. Species of this trematode fluke that involve the intestines include S. japonicum, S. mansoni, and S. mekongi, as opposed to S. haematobium, which tends to affect the urinary tract and is only occasionally found in the $\mathrm{Gl}$ tract. The schistosomes penetrate the dermis and blood vessel walls, eventually reaching the liver, where they feed on red blood cells, mature, and mate in the liver vasculature. Females lay eggs in the vessels, which migrate to the intestine, infiltrate the wall to reach the lumen, and are shed in the stool [49]. Stool ova and parasite studies may be negative in IS patients and peripheral blood eosinophils may not be elevated in chronic disease as compared to acute schistosomiasis [50-52]

Colonoscopically, IS tends to cause yellow, granular or "sandy" appearing mucosa or polyp formation. Ulcers may be seen, but not the cobblestoned appearance or longitudinal fissuring ulcers typical of Crohn's disease. Compared to Crohn's disease, IS tends to involve the left colon and rectum, whereas Crohn's disease affects small intestine and ascending colon more frequently.

Strictures and transmural involvement are uncommon but can occur (ब Table 5).
Resection specimens of IS may show submucosal fibrosis, noncaseating granulomas, and multinucleated giant cells with eggs. However, muscularis mucosa thickening, pyloric metaplasia, and crypt abscesses typical of Crohn's disease were not seen in IS according to one comparative study, and lymphoid aggregates were rare. Interestingly, contrary to what is expected, Crohn's disease patients may have more eosinophils in the lamina propria than is seen in IS. The worms may be seen in mesenteric veins.

On biopsy, granulomas and multinucleated giant cells may be present, but deeper sections may be necessary to reveal the eggs within the granulomas. The ova measure up to $180 \mu \mathrm{m}$ with a width of approximately $70 \mu \mathrm{m}$, and may be calcified (๑ Fig. 14). Inflammatory polyps and ulcers may be seen. Sometimes, little inflammatory response may be apparent surrounding the eggs. Crypt architectural distortion is uncommon, but can be seen in $25 \%$ of IS cases, mostly at the edges of ulcers. It is thought to be ischemia related from vascular occlusion by eggs.

\section{Outlook into the future}

By identifying the presence of CMV and other infectious causes for colitis, pathologic diagnoses can change patients' treatment. In addition to immunohistochemical and molecular tests, artificial intelligence (Al) may be a resource to aid pathologists in the future. Al could help direct pathologists to focus on the areas of tissue most suspicious for infectious organisms, particularly when dealing with vastly inflamed or necrotic tissue. It may also be useful in urgent clinical situations when immunohistochemical or molecular test results are not readily available.

\section{Conclusion}

The colon is subject to a wide variety of infectious agents. Accurate identification of the pathogen often requires definitive laboratory studies. The morphologic appearance of infectious agents in tissue is important to recognize, as some diseases, e.g., strongyloidiasis, schistosomiasis, and amebiasis, may go undetected as chronic disease and only be diagnosed by biopsy. Histopathologists play an important role in the management of immunocompromised patients, such as those with IBD, HIV, or transplants.

\section{Corresponding address}

\section{Maria Westerhoff, MD}

University of Michigan

2800 NCRC Building 35, 48109 Ann Arbor, MI, USA

mwesterh@med.umich.edu

\section{Declarations}

Conflict of interest. M. Westerhoff declares that she has no competing interests. 
For this article no studies with human participants or animals were performed by any of the authors. All studies performed were in accordance with the ethical standards indicated in each case.

\section{References}

1. Hissong E, Chen Z, Yantiss RK (2019) Cytomegalovirus reactivation in inflammatory bowel disease: an uncommon occurrence related to corticosteroid dependence. Mod Pathol 32:1210-1216

2. McCurdy JD, Enders FT, Jones A, Killian JM, Loftus EV Jr, Bruining DH et al (2015) Detection of cytomegalovirus in patients with inflammatory bowel disease: where to biopsy and how many biopsies? Inflamm Bowel Dis 21:2833-2838

3. Yan Z, Wang L, Dennis J, Doern C, Baker J, Park JY (2014) Clinical significance of isolated cytomegalovirus-infected gastrointestinal cells. Int J Surg Pathol 22:492-498

4. Jones A, McCurdy JD, Loftus EV Jr, Bruining DH, Enders FT, Killian JM et al (2015) Effects of antiviral therapy for patients with inflammatory bowel disease and a positive intestinal biopsy for cytomegalovirus. Clin Gastroenterol Hepatol 13:949-955

5. Zagórowicz E, Bugajski M, Wieszczy P, Pietrzak A, Magdziak A, Mróz A (2016) Cytomegalovirus infection in ulcerative colitis is related to severe inflammation and a high count of cytomegaloviruspositive cells in biopsy is a risk factor for colectomy. JCrohns Colitis 10:1205-1211

6. Liao X, Reed SL, Lin GY (2016) Immunostaining detection of Cytomegalovirus in gastrointestinal biopsies: clinicopathological correlation at a large academic health system. Gastroenterology Res 9:92-98

7. MaddoxA, Francis N, Moss J, Blanshard C, Gazzard B (1992) Adenovirus infection of the large bowel in HIV positive patients. JClin Pathol 45:684-688

8. Sedláček P, Petterson T, Robin M, Sivaprakasam P, Vainorius E, Brundage T et al (2019) Incidence of adenovirus infection in hematopoietic stem cell transplantation recipients: findings from the AdVance study. Biol Blood Marrow Transplant 25:810-818

9. CesaroS, Berger M, TridelloG, Mikulska M, Ward KN Ljungman P et al (2019) A survey on incidence and management of adenovirus infection after allogeneic HSCT. Bone Marrow Transplant 54:1275-1280

10. La Rosa AM, Champlin RE, Mirza N, Gajewski J Giralt S, Rolston KV et al (2001) Adenovirus infections in adult recipients of blood and marrow transplants. Clin Infect Dis 15:871-876

11. Azad AK, Islam $R$, Salam MA, Alam AN, Islam M Butler T (1997) Comparison of clinical features and pathologic findings in fatal cases of typhoid fever during the initial and later stages of the disease. Am JTrop Med Hyg 56:490-493

12. Lamps LW, Madhusudhan KT, Greenson JK, Pierce RH, Massoll NA, Chiles MC et al (2001) The role of Yersinia enterocolitica and Yersinia pseudotuberculosis in granulomatous appendicitis: a histologic and molecular study. Am J Surg Pathol 25:508-515

13. Debi U, Ravisankar V, Prasad KK, Sinha SK, Sharma AK (2014) Abdominal tuberculosis of the gastrointestinal tract: revisited. World J Gastroenterol 28:14831-14840

\section{Histologie bei Dickdarminfektionen}

Hintergrund: Die histopathologische Diagnose der infektiösen Kolitis ist trotz der jüngsten Fortschritte in den mikrobiologischen Techniken immer noch wichtig. Ziele: In der vorliegenden Arbeit erfolgt die Beschreibung der histologischen Merkmale ausgewählter Infektionskrankheiten des Dickdarms, um Pathologen bei der Diagnose zu unterstützen.

Material und Methoden: Diagnosen zu histopathologischen und klinischen Aspekten von Koloninfektionserregern wurden zusammengestellt.

Ergebnisse: Obwohl die Histologie allein möglicherweise nicht so sensitiv ist wie aktuelle mikrobiologische Methoden, spielt die Identifizierung von Infektionserregern in Gewebe nach wie vor eine wichtige Rolle in der Patientenversorgung. Infektiöse Kolitiden können eine Vielzahl von klinischen Manifestationen haben, von Strongyloidiasis, die eine jahrzehntelang schwelende, subklinische Infektion verursachen kann, bis hin zur Syphilis, die klinisch Karzinome oder entzündliche Darmerkrankungen imitieren kann. Daher hat der histopathologische Nachweis einer Infektion als Ursache der Kolitis eines Patienten erheblichen Einfluss auf Behandlungsentscheidungen. Mikroskopisch können jedoch morphologische Überschneidungen zwischen Infektionen und anderen Krankheiten auftreten. Außerdem können einige Infektionen über die akute Kolitis hinaus verschiedene Gewebereaktionen auslösen. Bei Transplantationspatienten muss an Entzündungsreaktionen durch Krankheitserreger wie Zytomegalovirus (CMV) oder Adenovirus gedacht werden. Sexuell übertragene Proktokolitiden verursachen zumeist eine plasmazellreiche Entzündung. Bei der gastrointestinalen Histoplasmose liegt eher eine diffuse Histiozyteninfiltration vor, als dass Granulome gesehen werden. In manchen Fällen sind Zusatztests nützlich, aber mehrdeutige Ergebnisse können zu diagnostischen Dilemmata führen.

Schlussfolgerungen: Angesichts der Bandbreite, mit der sich Infektionskrankheiten des Dickdarms manifestieren können, ist der Zweck dieser Arbeit, Pathologen bei der Diagnose zu unterstützen, indem die typischen Merkmale der infektiösen Kolitis sowie zusätzlich Merkmale beschrieben werden, die über die klassische Morphologie hinausgehen, die üblicherweise berücksichtigt wird.

\section{Schlüsselwörter}

Gastrointestinale Pathologie · Virale Kolitis · Parasitäre Infektion · Bakterielle Kolitis · Sexuell übertragbare Proktitis

14. Horvath KD, Whelan RL (1998) Intestinal tuberculosis: return of an old disease. Am J Gastroenterol 93:692-696

15. Farhi DC, Mason UG 3rd, Horsburgh CR Jr. (1986) Pathologic findings in disseminated Mycobacterium avium-intracellulare infection. A report of 11 cases. Am J Clin Pathol 85:67-72

16. Cohen L, Guarner J, Hunt WR (2017) A novel presentation of Mycobacterium avium complex in a recipient of a lung transplant: a case report. J Med Case Rep 28:240

17. de Vries HJC, Nori AV, Kiellberg Larsen $\mathrm{H}$, Kreuter $\mathrm{A}$ Padovese V, Pallawela S et al (2021) 2021 European Guideline on the management of proctitis, proctocolitis and enteritis caused by sexually transmissible pathogens. J Eur Acad Dermatol Venereol 35:1434-1443

18. Afecto E, Fernandes S, Rodrigues A (2021) Rectal pseudotumor secondary to Chlamydia trachomatis: not everything is what it seems. Am J Gastroenterology 116:1578

19. Arnold CA, Roth R, Arsenescu R, Harzman A, LamHimlin DM, Limketkai BN et al (2015) Sexually transmitted infectious colitis vs inflammatory bowel disease: distinguishing features from a casecontrolled study. Am J Clin Pathol 144:771-781
20. Davis BT, Thiim M, Zukerberg LR (2006) Case records of the Massachusetts General Hospital. Case 2-2006. A 31-year-old, HIV-positive man with rectal pain. NEngl J Med 19:284-289

21. Waters KM, Cox BK, Wong MT, Guindi M, Kim SA, Larson BK et al (2021) Lymphogranuloma venereum (LGV) of the anorectum: evaluation of clinicopathological associations and the utility of a novel RNA in-situ hybridisation stain. Histopathology 78:392-400

22. Tse JY, Chan MP, Ferry JA, Deshpande V, Sohani AR, Nardi V et al (2018) Syphilis of the aerodigestive tract. Am J Surg Pathol 42:472-478

23. Ogata S, Shimizu K, Oda T, Tominaga S, Nakanishi K (2016) Immunohistochemical detection of human intestinal spirochetosis. Hum Pathol 58:128-133

24. Sangoi AR, Rogers WM, Longacre TA, Montoya JG, Baron EJ, Banaei N (2009) Challenges and pitfalls of morphologic identification of fungal infections in histologic and cytologic specimens: a ten-year retrospective review at a single institution. Am J Clin Pathol 131:364-375

25. Prescott RJ, Harris M, Banerjee SS (1992) Fungal infections of the small and large intestine. J Clin Pathol 45:806-811 
26. Thomson SR, Bade PG, Taams M, Chrystal V (1991) Gastrointestinal mucormycosis. Br J Surg 78:952-954

27. Ribes JA, Vanover-Sams CL, Baker DJ (2000) Zygomycetes in human disease. Clin Microbiol Rev 13:236-301

28. Nemenqani D, Yaqoob $N$, Khoja $H$, Al Saif $O$, Amra NK, Amr SS (2009) Gastrointestinal basidiobolomycosis: an unusual fungal infection mimicking colon cancer. Arch Pathol Lab Med 133:1938-1942

29. Vs V, Hallur V, Samal S, Chouhan MI, Bhat SJ, Kumar P et al (2021) Basidiobolomycosis of right colon mimicking as carcinoma of colon. ACG Case Rep J 14:e573

30. Lamps LW, Molina CP, West AB, HaggittRC, ScottMA (2000) The pathologic spectrum of gastrointestinal and hepatic histoplasmosis. Am J Clin Pathol 113:64-72

31. Kahi CJ, Wheat LJ, Allen SD, Sarosi GA (2005) Gastrointestinal histoplasmosis. Am J Gastroenterol 100:220-231

32. Rajeshwari M, Xess I, Sharma MC, Jain D (2017) Acid-fastness of histoplasma in surgical pathology practice. JPathol Transl Med 51:482-487

33. Araujo SA, Nascentes Queiroz TC, Demas Alvares Cabral MM (2010) Colonic leishmaniasis followed by liver transplantation. Am JTrop Med Hyg 83:209

34. Praneenararat S (2014) Fungal infection of the colon. Clin Exp Gastroenterol 21:415-426

35. Rocha N, Suguiama EH, Maia D, Costa H, Coelho KI, Franco M(1997) Intestinal malakoplakiaassociated with paracoccidiodomycosis: a new association. Histopathology 30:79-83

36. Beshoy Y, Nneji J, Buxbaum J (2015) A case of the hiccups in the setting of colonic ulcers. Gastroenterology 148:e8-e9

37. Smith G, Hoover S, Sobonya R, Klotz SA (2011) Abdominal and pelvic coccidioidomycosis. Am J Med Sci 341:308-311

38. Washington K, Gottfried MR, Wilson ML (1992) Gastrointestinal cryptococcosis. Mod Pathol 4:707-711 (Erratum in: Mod Pathol 1992 Mar;5(2):211.)

39. Haque R, Huston CD, Hughes M, Houpt E, Petri WA Jr (2003) Amebiasis. NEngl J Med 17:1565-1573

40. Fleming $R$, Cooper CJ, Ramirez-Vega R, HuertaAlardin A, Boman D, Zuckerman MJ (2015) Clinical manifestations and endoscopic findings of amebic colitis in a United States-Mexico border city: a case series. BMC Res Notes 14:781

41. Dorantes JA, López-Becerril JO, Zavala-Cerna MG (2021) Fatal attraction: intestinal amebiasis and COVID-19 as risk factors for colonic perforation JSurg Case Rep 23:rjab301

42. Takahashi T, Gamboa-Dominguez A, GomezMendez TJ, Remes JM, Rembis V, MartinezGonzalez D et al (1997) Fulminant amebic colitis: analysis of 55 cases. Dis Colon Rectum 40:1362-1367

43. Ning TZ, Kin WW, Mustafa S, Ahmed A, Noordin R, Cheong TG et al (2012) Detection of entamoeba histolytica in experimentallyinduced amoebicliver abscess: comparison of three staining methods. Asian Pac J Trop Biomed 2:61-65

44. Roseman DA, Kabbani D, Kwah J, Bird D, Ingalls R, Gautam A et al (2013) Am J Transplant 13:2483-2486

45. Nutman TB (2017) Human infection with Strongyloides stercoralis and other related Strongyloides species. Parasitology 144:263-273

46. Minematsu H, Hokama A, Makishi T, Arakaki K, Kinjo F, Fujita J (2011) Colonoscopic findings and pathologic characteristics of Strongyloides colitis: a case series. Digestion 83:210-214

47. Rivasi F, Pampiglione S, Boldorini R, Cardinale $L$ (2006) Histopathology of gastric and duodenal Strongyloides stercoralis locations in fifteen immunocompromised subjects. Arch Pathol Lab Med 130:1792-1798

48. Ramdial PK, Hlatshwayo NH, Singh B (2006) Strongyloides stercoralis mesenteric lymphadenopathy: clue to the etiopathogenesis of intestinal pseudo-obstruction in HIV-infected patients. Ann Diagn Pathol 10:209-214

49. Olveda DU, Li Y, Olveda RM, Lam AK, Chau TN, Harn DA et al (2013) Bilharzia: pathology, diagnosis, management and control. Trop Med Surg 20:135

50. Ross AG, Bartley PB, Sleigh AC, Olds GR, Li Y, Williams GM et al (2002) Schistosomiasis. N Engl J Med 18:1212-1220

51. Cai L, Chen Y, Xiao SY (2021) Clinicopathologic features of chronic intestinal Schistosomiasis and its distinction from Crohn disease. Am JSurg Pathol 45:430-438

52. Strickland GT (1994) Gastrointestinal manifestations of schistosomiasis. Gut 35:1334-1337

\section{Emeditorial
Manager}

\section{Hilfestellungen für den Editorial Manager}

Das Einreichungs- und Begutachtungssystem Ihrer Zeitschrift

Sowohl für die ganz alltäglichen Fragen in der Handhabung des Editorial Managers als auch für spezielle Problematiken finden Sie auf www.springermedizin.de/editorialmanager eine Vielzahl an Handreichungen, die Ihnen die Arbeit als Gutachter*in, Autor*in oder Herausgeber*in erleichtern.

Über Videos, einseitige Schritt-für-SchrittAnleitungen oder ein umfangreiches Manual werden Sie durch die einzelnen Punkte geführt, wie:

- Wie reiche ich ein Manuskript ein?

- Wie finde ich passende Gutachter*innen?

- Wie lade ich Gutachter*innen ein?

- Wie nehme ich ein Gutachten an bzw. lehne es ab?

- Wo erkenne ich, in welchem Status ein Mansukript ist?

- Wie ändere ich meine persönlichen Informationen?

- Wo kann ich meinen Urlaub eintragen?

Zugang auch über QR-Code:

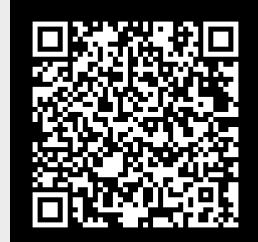

